\title{
Empirical Investigation of Free Cash Flow Hypothesis: Evidence from Jordanian Capital Market
}

\author{
Ziad Zurigat ${ }^{1}$, Iaad I. S. Mustafa Sartawi ${ }^{1} \&$ Hasan Aleassa ${ }^{1}$ \\ ${ }^{1}$ Faculty of Economics \& Administrative Sciences, Yarmouk University, Jordan \\ Correspondence: Iaad I. S. Mustafa Sartawi, Faculty of Economics \& Administrative Sciences, Yarmouk \\ University, Irbid, 21163, Jordan. Tel: 962-2-7244-964. E-mail: sartawi@yu.edu.jo
}

Received: December 6, 2013

Accepted: January 31, 2014

Online Published: February 24, 2014

doi:10.5539/ibr.v7n3p137

URL: http://dx.doi.org/10.5539/ibr.v7n3p137

\begin{abstract}
This study aims to investigate free cash flow hypothesis proposed by Jensen (1986). Data pertaining to 102 non-financial firms listed on ASE during the period of 1998-2009 are analyzed using pooled and panel data methods. Contrary to Jensen (1986) proposition, we found that debt and dividend are not substitute techniques for mitigating agency costs of free cash flow in the Jordanian capital market, rather, they are complementary to each other. However, debt is used more than dividend for stability consideration of dividend policy where the use of debt and dividend is largely affected by dividend smoothing and leverage target adjustment considerations. Moreover, we found that low growth firms use debt more than dividends.
\end{abstract}

Keywords: agency costs, free cash flows, Jordanian capital market, dividend smoothing, leverage target adjustment

\section{Introduction}

The "classic" propositions made by Modigliani \& Miller $(1958,1963)$ ignore the presence of information, agency and bankruptcy costs. They assume that managers acts exclusively for shareholders benefits with no information asymmetry, so investors and management possess the same information about the firm's future potential investments. The dismissal of information and agency costs makes capital market perfect and consequently, capital structure irrelevant. Contrast to what has been suggested by Modigliani and Miller (1958; 1963), Jensen and Meckling (1976), Myers (1977), and Jensen (1986) amongst others, provide evidence suggesting that managers may place their personal goal or interests ahead of those of shareholders. A case where a conflict of interest between managers and shareholders is created. As managers have more knowledge than outsiders, their investment and financing decisions may be interpreted by outsiders in a way that may increase the costs of issuing debt and equity, and accordingly increase the firms' reliance on internal funds (Myers, 1984; Myers \& Majluf, 1984). Jensen and Meckling (1976) suggest that the separation of ownership and management encourages managers to give the priority for their own interests or benefits. This situation creates agency costs incurred by the owners who should work effectively to reduce the effect of these costs on their wealth. Gillan and Starts (2003) pointed out that the agency problem may be magnified by the disperse nature of corporate ownership. This is because small shareholders have no incentive for bearing the cost of controlling the management behavior.

The agency problem and its costs will be more severe in the presence of free cash under management control. Following the agency theory logic, it is reasonable to assume that managers might tend to invest in poor investment opportunities or to overvalue the investment requirements for their own benefits. Because of their information advantage, Grenadier and Wang, (2005) argue that managers may set investment financing requirements over their real value and use the difference between the real and dummy balances for their own benefits. Jensen (1986) addressed the agency problem under conditions of the free cash flow theory. However, Stulz (1990) properly modeled this theory. The Free cash flow theory of Jensen (1986) suggests that the availability of free cash flow under management control will induce them to invest the extra cash in unprofitable projects (negative NPV projects), creating an over-investment problem, and consequently increasing the costs incurred by shareholders. These costs are called "over-investment costs". The over-investment behavior is motivated by managers' enticement to drive their firms to grow away from the optimal size, which increases the funds under their control, and consequently increases their power. According to Stulz (1990), managers want to 
invest all surplus funds even if paying dividends enhances the firm's value and thereby the shareholders, wealth. Likewise, managers choose to keep on a firm's operations even though liquidating the firm is the best choice for owners (Harries \& Raviv, 1990).

Different techniques have been suggested by the literature as mechanisms for mitigating the agency costs. While some of these techniques such as incentives and performance plans are set to reduce the moral hazards and induce managers to work for the shareholders' benefit, other techniques like debt and/or dividend are used to avoid over-investment problem or wasting the firm's free cash flow in consuming more perquisites (Frankurter \& Wood, 2002). Jenson (1986) argues that debt and dividend work as substitutes techniques to line up the interests of managers with those of shareholders, and consequently mitigating the agency problem of free cash flow. On the other hand, debt contracts, legally, bond the firm to the principal and interest payments, thus reducing the amount of surplus cash under management control, and consequently, the agency cost. Moreover, it motivates managers to take the optimal investment decisions that maximize the firm's value (Lasfer, 1995) to avoid default, which gives creditors the authority to liquidate the firm (Harris \& Raviv, 1990).

It is worth noting that Jensen (1986) posits that debt will be an effective tool for mitigating the agency costs of free cash flow in firms having poor investment opportunities with a large amount of extra funds, where the probability of using these funds in carrying out negative NPV projects is high. Moreover, he suggests that creating debt without retention of the proceeds of the issue, bonds managers to maintain their commitment to make the interest and principal payments to the debtholders, and thus making debt an effective substitute for dividends (Lang \& Lizenberger, 1989). However, debt may give managers the incentive to invest sub-optimally, thus reducing the firm's value, and consequently creating new conflict between shareholders and debtholders (Jensen \& Meckling, 1976; Watts \& Zimmerman, 1986). According to Lasfer (1995), investing debt funds in risky projects will benefit shareholders at the expense of debtholders. This is because shareholders have a limited liability toward the debtholders who will be the losers if the project fails. The market may anticipate the value-reducing behavior of managers, and accordingly prices the debt. This increases the cost of raising funds through debt, and consequently, forces firms to forgo some of their positive NPV projects. Therefore, Myers (1977) shifted the firms' interest for saving their debt capacity reserve to pass up the under-investment problem.

As suggested by Jensen (1986) pay out free cash, as dividends tends to decrease discretionary funds under management control, and hence coincide the interests of managers with those of shareholders (Rozeff, 1982; Easterbrook, 1984). Dividends, like debt, give the rise to the potential conflict between shareholders and debtholders because the excess dividend payment may be interpreted by debtholders as an expropriation of their wealth (asset substitution problem) (Jensen \& Meckling, 1976). Watts and Zimmerman, (1986) argue that managers may create debt and pay part of this debt as a dividend to existing shareholders leaving old and new debtholders without sufficient cash to pay their debt claims which magnifies shareholders and debtholders conflict. Therefore, debtholders will have the incentive to restrict the firm's dividend payment to insure their claim payments.

Although debt and dividend work as substitutes technique for avoiding the agency problem of free cash flow, shareholders generally favor cash dividend to restrict managers from wasting discretionary funds for the following considerations: first, paying cash dividend reduces the amount of free cash for investment in negative NPV projects and thereby over-investment problem (Lang \& Lizenberger, 1989). Second, similar to debt, dividend conveys news about the firm's performance and value (Fama \& French, 2002). However, contrasting debt, the news conveyed by dividend about the firm's profitability are good ones (positive signal), and thus increases the value of firm. Third, dividend increases help shareholders to control managers' behavior at the lowest possible cost. Finally, unlike debt, cash dividends tend to reduce free cash flow directly, while debt may increase funds under management control, inducing them to use debt funds for their own benefits or sub-optimally investment (Watts \& Zimmerman, 1986).

It is worth noting that firms that apply a steady dividend policy may not use the dividend to solve the agency problem of free cash flow. As Lintner (1956) suggests, firms increase dividend only if they believe that there is a permanent increase in their earnings or they can sustain the new level of dividend payment. Consistent with this argument, Baskin (1989) points out that managers and shareholders adopt their expectations about future dividend payments based on their prior payments. Accordingly, larger past dividend will imply the greater need for cash in the future, forcing managers to raise debt funds, and consequently increasing the probability of bankruptcy risk (Easterbrook, 1984).

Thus, although debt and dividend work as substitute techniques for reducing the agency costs, the use of debt or dividend is subject to many considerations such as those discussed above. In addition, the choice may depend on 
other considerations such as the market where the firm operates- developed vs. less developed-, the financial system followed- market vs. bank-based-, the presence of large institutional shareholders, and the extent to which information and agency cost are severe. Different views have suggested that information asymmetries, bankruptcy cost, and agency costs of debt are more severe in less developed capital markets. These markets are characterized by low competition and liquidity, and the absence of both compatible regulations and sufficient supervision. Therefore, financing and investment decisions in these markets differ from those made in developed capital markets. (Mayer, 1990; Kunt \& Maksimovic, 1994). Fazzari, Hubbard, \& Petersen (1988), and Charlton, Lancaster, \& Stevens (2002) amongst others, provide evidence indicating that market frictions are matter for developed markets as well as for developing markets but in different degrees due to the differences in the transparency and investor protection levels.

In Jordan, where the capital market is imperfect, market frictions such as information asymmetry and agency costs are applicable. It is a thin and a small market. Managers of Jordanian firms listed in this market have less than $4 \%$ investment in these firms, making the presence of agency conflicts and information asymmetries more likely and more severe than would be in a developed capital market. Information asymmetries and agency costs restrict the firms' ability not only to raise funds externally (Jensen \& Meckling, 1976; Warner, 1977; Myers, 1984; Myers \& Majluf, 1984; Jensen, 1986), but also to raise funds internally through retained earnings (Baskin, 1989), supporting the information content of dividend payments.

Financial liberalization has been adopted in Jordan since 1990. This resulted in removing the barriers that restrict the firms' access to external financing. Consequently, the firms' reliance on internally generated capital decreases. In addition, their ability to save cash for paying dividends increases. However, the use of debt and dividend by the Jordanian firms to reduce the agency costs of free cash flow is still under investigation. Moreover, the existing empirical studies are skewed to developed capital markets. Therefore, the current study aims to enrich the existing research by investigating how Jordanian listed firms deal with the presence of agency problem of free cash. More specifically, it investigates whether Jordanian listed firms use debt or dividend and to what extent their behavior is in line with the theoretical explanations of the free cash flow agency theory.

Because of the nature of its capital market, Jordan is considered an ideal model for testing the free cash flow of agency theory and the other theories of dividend and capital structure and their implications for developing countries. Too much effort has been spent, and plenty of decisions have been taken to shift Jordan into the world market. These efforts created a considerable conversion of the institutional system, provided the financial managers with the flexibility to choose their financing and dividend patterns, and consequently affected the mix of debt and equity.

The remainder of the study is organized as follows: section 2 presents the sample, data, and empirical model specifications. Section 3 reports and analyzes the results of the estimated empirical models with some investigations of the effects of firm specifics on the technique that a firm chooses to avoid the agency costs of free cash flow. Section 4 presents the summary and conclusion.

\section{Method}

\subsection{Model Specification}

The empirical model specification used in the current study to test the free cash flow hypothesis is built depending on the model that has been developed and used by Shyam-Sunder and Myers, (1999); and Frank and Goyal (2003) to test the pecking order theory of capital structure. More precisely, they empirically test the financing behaviour of firms when they experience financial deficit. Frank and Goyal, (2003) argue that firms that follow pecking order theory will use debt to face financial deficit. However, they say nothing when firms having surplus rather than deficit. Jensen (1986) concludes that the availability of cash surplus (financial surplus) under management control will magnify the conflict of interest between managers and shareholders, increasing monitoring costs and consequently reducing the firm's value. Therefore, Jensen (1986) pays the attention to the use of debt or dividend as efficient techniques to reduce the agency costs of having free cash flows.

It is worth noting that free cash flow is defined as the cash flow that exceeds what is needed for financing all positive net present value projects when they are discounted at the cost of capital (Jensen, 1986, p. 323). The cash flows statement suggests that cash generated must equal cash used. If the generated cash is less than the cash used, firms may raise external funds to finance their cash deficit, otherwise, they may tend to retire debt or raise debt or increase dividend payments depending on whether they face severe agency and bankruptcy costs of debt. Following Shyam-Sunder and Myers, (1999); Frank and Goyal (2003) suggestions that cash deficit or cash surplus (free cash) exists if internal cash flow, dividend, and actual investment opportunities are imbalanced. This can be formalized as follows: 


$$
C F_{i t}^{\text {deficit }} \text { orCF } F_{i t}^{\text {free/ surpus }}=D V_{i t}+I_{i t}+\Delta W C_{i t}-C F_{i t}
$$

Based on equation (1)

cash deficit $\left(C F_{i t}^{\text {deficit }}\right)$ exists if $D V_{i t}+I_{i t}+\Delta W C_{i t}>C F_{i t}$,

while, cash surplus $\left(C F_{i t}^{\text {free/surplus }}\right)$ exists if $D V_{i t}+I_{i t}+\Delta W C_{i t}<C F_{i t}$.

Where,

$D V_{i t}$ is the cash dividend payments of firm $\mathrm{i}$ in year $\mathrm{t}$

$I_{i t} \quad$ is the net investment (capital expenditures) of firm $\mathrm{i}$ in year $\mathrm{t}$ and calculated as the difference between fixed assets at $\mathrm{t}-1$ and $\mathrm{t}$ for each firm.

$\Delta W C_{i t} \quad$ is the change of working capital for firm $\mathrm{i}$ in year $\mathrm{t}$. It is calculated as the difference between working capital at $\mathrm{t}-1$ and $\mathrm{t}$ for each firm while the working capital (WC) is calculated as the difference between current assets (CA) and current liabilities (CL).

$C F_{i t} \quad$ is the operating cash flow after interest and taxes for firm $\mathrm{i}$ in year $\mathrm{t}$.

In the context of his free cash flow hypothesis, debt and dividend are used as substitute techniques to minimize funds under management control. The total amount of debt issued or dividend paid from one period to another should equal the amount of excess cash available at the end of that period. This can be formalized as:

$$
\Delta D_{i t} \text { or } \Delta D V_{i t}=C F_{i t}^{\text {free/ surplus }}
$$

If firms use debt to avoid the agency cost of free cash flow, $\Delta D V_{i t}=0$, while if they use dividend, $\Delta D_{i t}=0$,

implying that:

$$
\Delta D_{i t}=\lambda_{0}+\lambda_{1} C F_{i t}^{\text {free/ surplus }}+\varepsilon_{i t}
$$

Or,

$$
\Delta D V_{i t}=\varphi_{0}+\varphi_{1} C F_{i t}^{\text {free/surplus }}+\varepsilon_{i t}
$$

To avoid the presence of heteroskedasticity problem that might result when firms of differing size are considered, all variables included in this study are scaling by total assets. $\lambda_{i}$ and $\varphi_{i}$ are the coefficients to be estimated. $\lambda_{1}$ should equal one if debt is used to avoid the agency cost of free cash flow. However, the existence of one-to-one association will be for firms with borrowing below their debt capacity. Moreover, they may use free cash flow to retire debt instead of raising debt. If dividend is used, $\varphi_{1}$ should be one. $\varphi_{1}$ is expected to be one for firms with unstable dividend policy while for those with stable dividend, $\varphi_{1}$ will be less than one. The mixed use of debt and dividend results in less than one coefficients for both debt and dividend.

In case of developing capital markets, creating debt may be restricted by agency and bankruptcy costs of debt which in turn restricts the use of dividend policy to reduce the probability of using free cash flow in the way that may affect the firm's value. Hence, one could expect that dividend may be used jointly with debt to mitigate the agency costs of free cash flow. This suggests that One-to-one relationship will not exist for dividend and debt.

Pooled and panel regressors will be applied to test all empirical models in this study. Fixed effect model and random effect models are used to regress panel data set. As Gujarati, (2003) points out that panel data is used to control for the effects of the unobserved firm and time-specific variables on the dependent variable. Hence, Ordinary Least Square technique (OLS) will be the best specification for testing pooled data sample set when individual or time-specific factors do not exist. For the purpose of determining which is the best specification for running data set, Breusch and Pagain (1980) Lagrange multiplier (LM) is applied to test the null hypothesis that the cross-sectional variance components are zero $(\mathrm{H} 0: 62=0)$. The Hausman test is used in the current study for testing the null hypothesis that the random and fixed estimators generate the same efficient coefficients.

\subsection{Sample and Data}

The sample of this study consists of all non-financial firms listed on the Amman Stock Exchange (ASE) over the period of 1998-2009. The study applied the following sampling criteria: first, all firms that have been engaged in merger or liquidated during the study period are not included. Second, Firms that have missing data are also no included; finally, firms established after year 1998 are not included. Applying the above sample selection criteria creates a balanced panel data and confines the study to 102 non-financial firms with data continuously available 
for 12-year period (between 1998 \& 2009). Data are collected from firms' annual reports, and the Yearly Shareholding Companies Guide available online at ASE webpage.

\section{Results}

The results of the Lagrange Multiplier (LM) and Hausman tests show that the random effects regressor is more effective than other regressor to generate efficient estimations. LM found to be statistically significant at $1 \%$ level while Huasman test found to be statistically insignificant. However, the acceptance of random effect regressor as an efficient and consistent estimator does not mean that the fixed effect estimator is not efficient (Gujarati, 2003). Hence, we report and discuss the results of both random and fixed effects models.

Table 1. Estimation results of model 3 (dependent variable: $\Delta D_{i t}$ )

\begin{tabular}{lcc}
\hline Independent variable & Fixed effects model & Random effects model \\
\hline Intercept & $1.041^{*}$ & $0.801^{*}$ \\
& $(0.000)$ & $(0.002)$ \\
$C_{\text {it }}^{\text {free/ surplus }}$ & $0.412^{*}$ & $0.433^{*}$ \\
& $(0.022)$ & $(0.005)$ \\
$\mathrm{R}^{2}$ & 0.55 & 0.57 \\
$\mathrm{P}$-value & $(0.000)$ & $(0.000)$ \\
$\mathrm{N}$ & 1224 & 1224 \\
LM Test & - & 222.13 \\
& & $(0.000)$ \\
Hausman Test & 1.79 & - \\
\hline
\end{tabular}

Table 2. Estimation results of model 4 (dependent variable: $\Delta D V_{i t}$ )

\begin{tabular}{ccc}
\hline Independent variable & Fixed effects model & Random effects model \\
\hline Intercept & $0.841^{*}$ & $1.021^{*}$ \\
$C F_{\text {it }}^{\text {free/ surplus }}$ & $(0.002)$ & $(0.012)$ \\
& $0.193^{*}$ & $0.182^{*}$ \\
$\mathrm{R}^{2}$ & $(0.002)$ & $(0.015)$ \\
P-value & 0.48 & 0.51 \\
$\mathrm{~N}$ & $(0.000)$ & $(0.000)$ \\
LM Test & 1224 & 1224 \\
& - & 212.17 \\
Hausman Test & & $(0.000)$ \\
& $(0.998)$ & - \\
\hline
\end{tabular}

The results presented in Tables 1 and 2 suggest that Jordanian firms tend to use both debt and dividend to avoid the agency costs of free cash flow, indicating that dividend and debt are not substitutes techniques to minimize the agency cost of free cash flow as suggested by Jensen (1986). However, the propensity of using debt is higher than that of using dividend. In both equations, the estimated coefficients of $C F_{i t}^{\text {free/surplus }}$ are statistically significant and different from one (not one as they are assumed to be). They are 0.433 and 0.182 in debt and dividend equations respectively. In both equations, the intercepts' coefficients are found to be statistically significant, implying that other techniques such as incentive and compensation plans are used jointly with debt and dividend to handle the agency costs of free cash flow. Another explanation could be attributed to the fact that 
Jordanian firms follow steady dividend payout policy, making financial managers more reluctant to reduce or cut cash dividend payments. This implies that dividend payout will change only if managers insure the sustainability of the new dividend payout ratio. The finding of Omet (2004) largely supports this explanation. His finding suggests that Jordanian listed firms identify a long-run target dividend payout ratio and shift steadily towards that target but at relatively low rates of target reversion, implying a dividend smoothing behavior. Although the estimated coefficient of $C F_{i t}^{\text {free/surphus }}$ is higher for debt than for dividend, it still less than expected, suggesting that Jordanian firms may use free cash flow to retire rather than to raise debt. This suggests that the agency cost of the asset substitution problem is higher than that of free cash flow, making the benefits of reducing debt higher than increasing debt. By considering the bankruptcy costs and tax benefits of debt, increasing or reducing debt may be restricted to whether Jordanian firms are below or above the target leverage ratio, which may affect the use of debt when free cash flow exists. Moreover, it may be affected by whether Jordanian firms face low or high growth in their investment opportunities and whether they have large institutional shareholders. These considerations are tested in the following subsections. In both equations, intercept coefficients are found to be statistically significant, implying that other techniques such as incentive and compensation plans are used jointly with debt and dividend to handle the agency costs of free cash flow.

\subsection{Above Versus below Leverage/ High Versus Low Payout}

In the context of trade-off theory, debt involves costs and provides benefits, which may determine the maximum level of debt that firms can use, especially for value-maximizing firms. These firms identify their target leverage at the point where the marginal cost of an additional unit of debt balances its marginal benefit (Barclay \& Smith 1995). The costs of debt consist of the bankruptcy costs and the agency costs of assets substitution, whilst the benefits are tax shield and the reduction in the agency costs of free cash flow (Tong \& Green, 2005). Deviation from the target leverage ratio motivates firms to, gradually, change their actual leverage ratio until deviation from that target disappears. However, the speed of target reversion may depend on whether the firm is below or above the target. It also depends on the bankruptcy law and tax regime applied in the country. For firms with leverage above the target leverage ratio, the costs of debt are expected to be higher than its benefits. This makes the benefit of reducing debt higher than that of increasing debt to reduce the agency cost of free cash flow. While for those firms with leverage below the target, the opposite is true. As the target leverage ratio is unobservable, the literature suggests three proxies to measure it: (i) the estimated fitted values from the conventional leverage equation (Flannery \& Rangan, 2006), (ii) the mean of the firm's leverage ratio over the study period (Shyam-Sunder \& Myers, 1999), and (iii) the industry mean over the study period (Cai \& Ghosh, 2003). As the firm's historical leverage mean reduces the impact of momentary variations in time due to business cycles, transaction costs and firms' lagged adjustments towards their target leverage ratios (Lo \& Hui, 2009), we consider the mean of firm's leverage ratio over the study period to calculate positive and negative deviations from the target as follows:

$$
d e v_{i t}=l e v_{i t}^{*}-l e v_{i t}
$$

Where, $l e v_{i t}^{*}>l e v_{i t}$ generates leverage below its target leverage level (negative deviation- $d e v_{i t}^{\text {negative }}$ ), while $l e v_{i t}^{*}<l e v_{i t}$ generate leverage above its target leverage level (positive deviation- $d e v_{i t}^{\text {positive }}$ ). $D_{i t}^{a b o v e}$ is a dummy variable which equals one for leverage above the target level ( $\left.d e v_{i t}^{\text {positive }}\right)$ and zero otherwise $\left(d e v_{i t}^{\text {negative }}\right)$.The dummy variables are used to differentiate between free cash flow with positive and negative deviation (above and below-target leverage ratio. Myers (1977) suggests that firms should save their debt capacity reserve to pass up underinvestment problems. The free cash flow theory of Jensen (1986) does not consider whether the firms that have free cash flow are above or below their target leverage ratio. More precisely, it ignores the possibility that firms with free cash flow have a target leverage ratio, which may force them to increase or reduce debt to make leverage-target reversion. 
Table 3. Estimation results of model 3 and 4 using the random effect model (Dependent variable: $\Delta D_{i t}$, $\left.\Delta D V_{i t}\right)$

\begin{tabular}{|c|c|c|c|c|}
\hline Independent variable & $\begin{array}{c}\text { Below } \\
\text { target-leverage }\end{array}$ & $\begin{array}{c}\text { Above } \\
\text { target-leverage }\end{array}$ & $\begin{array}{c}\text { Low } \\
\text { payout ratio }\end{array}$ & $\begin{array}{l}\text { High payout } \\
\text { ratio }\end{array}$ \\
\hline \multirow[t]{2}{*}{ Intercept } & $1.841^{*}$ & $1.021 *$ & 2.510 & 1.757 \\
\hline & $(0.052)$ & $(0.008)$ & $(0.421)$ & $(0.754)$ \\
\hline \multirow[t]{2}{*}{$C F_{i t}^{\text {free/ surplus }}$} & $0.373 *$ & $0.741 *$ & $0.207^{*}$ & 0.286 \\
\hline & $(0.002)$ & $(0.060)$ & $(0.015)$ & $(0.190)$ \\
\hline $\mathrm{R}^{2}$ & 0.48 & 0.46 & 0.38 & 0.32 \\
\hline P-value & $(0.000)$ & $(0.000)$ & $(0.000)$ & $(0.000)$ \\
\hline $\mathrm{N}$ & 757 & 467 & 807 & 417 \\
\hline \multirow[t]{2}{*}{ LM Test } & 191.93 & 211.54 & 112.03 & 105.91 \\
\hline & $(0.000)$ & $(0.000)$ & $(0.000)$ & $(0.000)$ \\
\hline \multirow[t]{2}{*}{ Hausman Test } & 5.15 & 1.89 & 2.23 & 7.02 \\
\hline & $(0.817)$ & $(0.828)$ & $(0.952)$ & $(0.721)$ \\
\hline
\end{tabular}

The re-estimation of model (3) using the dummy variable $D_{i t}^{\text {above }}$ provides results suggesting that Jordanian firms with free cash flow behave asymmetrically to positive and negative deviations from their target. The results presented in Table 3 show that Jordanian firms use free cash flow to retire debt when they are above the target or at least they will not use debt to soak up the free cash, while they use debt to absorb the extra free cash flow when they are below the target. Different explanations could be reasonable. First, the majority of shareholders of Jordanian listed firms are institutional shareholders. According to Jensen and Meckling (1976), institutional shareholders are expected to work for the benefits of other shareholders, which reduce the agency cost of free cash flow, and consequently reduce the need for issuing debt. Alternatively, shareholders have no power to force managers to create debt to absorb the extra cash. Second, the Jordanian bankruptcy regime enhances the direct and indirect bankruptcy costs. It emphasizes on benefits of lenders with less emphasis on those of the firm. Firms entering bankruptcy are liquidated at a higher cost, reducing their willingness to increase debt when they are having extra cash with leverage above the target level. While having extra cash with leverage below the target implies low costs of bankruptcy and asset substitution (agency cost) with high agency costs of free cash flow. These, along with the fact that low leverage generates tax benefits, makes the tax savings of rising debt higher than its costs, increasing the desire of Jordanian listed to increase debt to absorb the free cash, and to reach the level under which the firm's value is maximized. The estimated coefficient of $C F_{\text {it }}^{\text {free/surplus }}$ with positive deviation- $d e v_{i t}^{\text {positive }}$ makes explanation more reasonable. For above-target leverage with free cash flow, the estimated coefficient on $C F_{\text {it }}^{\text {free/surplus }}$ variable is found to be statistically significant $(0.741)$ compared with 0.433 when deviation from the target level is not considered. However, the impetus of using free cash flow to eliminate the negative deviation was not significantly large. For below-target leverage with free cash flow, the estimated coefficient on $C F_{i t}^{\text {free } / \text { surplus }}$ variable is found to be statistically significant at a value of $(0.373)$. This finding may be attributed to the features of the tax scheme in Jordan. This system in addition to the bankruptcy law, provides firms with no incentives to raise debt for tax deliberation.

For high and low dividends payout, we look at the medium to split the sample firms into high and low dividend-paying firms. Firms with dividends above the median are classified as high dividend firms $\left(D_{i t}^{\text {high-DV}}=1\right)$, while those with dividend payment below the median are classified as low dividend firms $\left(D_{i t}^{l o w-D V}=0\right)$. The estimation results of model 4 for low and high dividend (Table 3 ) show that firms with high dividend payments will not pay more dividends to absorb free cash, while they increase their dividend payment to soak up surplus when they have low dividend payments. For firms with high dividend payment, the estimated coefficient is found to be statistically insignificant, implying that firms leave their dividend policy unchanged. This is because these firms will not increase dividend before making sure that the new level can be maintained, especially these firms have already high dividend payments, making managers highly hesitant to increase or even to cut dividends. For low dividend firms, the coefficient is found to be positive and statistically significant but it is not high, which implies that low dividend Jordanian firms use dividends to absorb free cash but their impetus to do that is not too high. This finding may be attributed to the tendency of Jordanian firms to stabilize 
their dividend policies. Moreover, the Jordanian capital market is not developed well enough. Thus, firms face difficulties when seeking funds externally. Fazzari, Hubbard, \& Petersen (1988) who argued that the low-target payout ratio firms are more financially constrained support this explanation. Therefore, the focus will be on keeping their debt capacity to avoid the underinvestment problem.

\subsection{High Versus Low Growth Opportunities}

Jensen (1986, p. 324) suggests that the use of debt as a control mechanism is more significant in firms that have huge cash flows with little growth opportunities. For these firms, the pressure to misuse the available free cash in non-valuable projects is crucial. Therefore, shareholders may want management to use debt so they (management) will have power over a limited size of extra cash (Stulz, 1990). As Harris and Raviv (1990) points out, debt exposes managers to the market discipline because default allows creditors the option to force the firm into liquidation. This motivates managers to work harder and make better investment decisions (Lasfer, 1995). Hence, firms that have a large amount of free cash flow with less valuable investment opportunities are expected to issue more debt, suggesting that high growth firms do not need to issue debt to soak up free cash flow. Consistent with this argument, Myers (1977) suggests the use of equity not debt for financing new investment opportunities for the purpose of maintaining the borrowing capacity for the future. These firms are expected to use their internal cash flow efficiently. In contrast, internal funds may be insufficient to finance their positive investment opportunities and, hence, they are likely to be in need of external funds to avoid forgoing positive NPV projects (Myers, 1984; Myers \& Majluf, 1984). Moreover, the agency costs of debt (asset substitution costs) are higher for high-growth firms than for low-growing firms, making the costs of issuing debt by low-growing firms lower than that of high-growth firms (see, Titman \& Wessels, 1988; Rajan \& Zingales, 1995).

To investigate the effect of free cash flow for high and low growing firms, we use the interaction dummy form. For this purpose, we use the ratio of market-to-book value as a proxy for growth opportunities (Rajan \& Zingles, 1995; Bevan \& Danbolt, 2004). Two dummy variables as additional explanatory variables with $C F_{i t}^{\text {free/surplus }}$ are used: $D_{\text {it }}^{\text {highrowth }}$ is a dummy variable, which equals one for high growing $(M / B>1)$ and zero otherwise $\left(M^{i t} / B<1\right)$ and the interaction dummy term variable as follows: $D_{i t}^{\text {high-growth }} * C F_{\text {it }}^{\text {free/ surplus }}$. The two dummy variables are considered for the purpose of differentiating between the slope and the intercepts estimated coefficients of free cash flow for low and high-growth firms (see, Gujarati, 2003, p. 308). By considering $D_{\text {it }}^{\text {highgrowth }}$ and $D_{i t}^{\text {high-growth }} * C F_{i t}^{\text {free/surplus }}$ model (3) can be rewritten as follows:

$$
\Delta D_{i t}=\psi_{0}+\psi_{1} D_{i t}^{\text {high-growth }}+\psi_{2} C F_{i t}^{\text {free/ surplus }}+\psi_{3}\left(D_{i t}^{\text {high-growth }} * C F_{i t}^{\text {free/surplus }}\right)+\varepsilon_{i t}
$$

$\psi_{1}$ is the differential intercept coefficient and measures the potential difference in the intercept for free cash flow with low and high-growth opportunities. $\psi_{3}$ is the differential slope coefficient and used to measure how much the slope coefficient of low-growth firms differs from that of high-growth ones. Accordingly, for growing firms, the intercept will be $\left(\psi_{0}+\psi_{1}\right)$, while the slope coefficient will be $\left(\psi_{2}+\psi_{3}\right)$.

For firm with $M / B>1: \Delta D_{i t}=\left(\psi_{0}+\psi_{1}\right)+\left(\psi_{2}+\psi_{3}\right) C F_{i t}^{\text {free/ surplus }}+\varepsilon_{i t} \ldots . .5 a$, While, for firms with $M / B<1: \Delta D_{i t}=\psi_{0}+\psi_{2} C F_{i t}^{\text {free/surplus }}+\varepsilon_{i t} \ldots 5 b$

The theoretical framework of interaction dummy term suggests that the statistically significant positive (negative) coefficient $\beta 3$ indicates -for non-growing firms with free cash flow- that the tendency of expanding debt will be higher (lower) than that of growing firms with free cash, while the insignificant $\psi_{3}$ suggests that firms will be indifferent between expanding debt or not. Similarly, a significant differential intercept coefficient $\psi_{1}$ suggests that the two estimators of surplus and deficit models have no identical intercept and vice versa. To test the null hypothesis that $\psi_{2}=\psi_{3}=0$. F-test is employed where the significant value of F-test leads to the rejection of the null hypothesis.

The results presented in Table 4 suggest that the difference in the intercept and slope coefficients are the source of the difference between the two regressions (restricted and unrestricted) as $\psi_{1}$ and $\psi_{3}$ are found to be statistically significant at $1 \%$. The positive slope coefficient implies that the impetus of increasing debt by low-growth Jordanian firms with free cash is lower than that of high-growth firms. This finding does not support what has been suggested by Titman and Wessels (1988); Rajan \& Zingales (1995); and Stulz, (1990) that low growing firms with free cash tend to issue more debt. One possible explanation of this finding is that, unlike high growing firms, managers of low growing firms may want to avoid the market discipline, therefore, they use dividend instead of debt to soak up their surplus. Furthermore, these firms are not followed up by large institutional shareholders who may force managers to create debt. Another explanation is that, low-growth firms 
Table 4. Estimation results of model 3 and 4 using the random effect model (Dependent variable: $\Delta D_{i t}, \Delta D V_{i t}$ )

\begin{tabular}{lcc}
\hline Independent variable & Model 3 & Model 4 \\
\hline Intercept & 2.124 & 1.605 \\
& $(0.000)$ & $(0.000)$ \\
$C F_{\text {it }}^{\text {free/ surplus }}$ & 0.321 & 0.408 \\
& $(0.004)$ & $(0.001)$ \\
$D_{\text {it }}^{\text {highgrowth }}$ & 0.124 & 0.124 \\
& $(0.048)$ & $(0.241)$ \\
$D_{\text {it }}^{\text {high-growth }} * C F_{\text {it }}^{\text {free/surplus }}$ & 0.206 & -0.126 \\
$\mathrm{R}^{2}$ & $(0.000)$ & $(0.014)$ \\
P-value & 0.57 & 0.53 \\
$\mathrm{~N}$ & $(0.000)$ & $(0.000)$ \\
LM Test & 1224 & 1224 \\
& 102.37 & 89.94 \\
Hausman Test & $(0.000)$ & $(0.000)$ \\
\end{tabular}

may try to save debt capacity to generate an acceptable level of financial flexibility to avoid forgoing valuable investment projects in the future. However, re-estimation of the dividend equation with respect to the growth opportunities makes the first explanation more reasonable. Model (3) will be reformulated using growth opportunities interaction term:

$$
\Delta D V_{i t}=\delta_{0}+\delta_{1} D_{i t}^{\text {high-growth }}+\delta_{2} C F_{i t}^{\text {free/surplus }}+\delta_{3}\left(D_{i t}^{\text {high-growth }} * C F_{i t}^{\text {free/surplus }}\right)+\varepsilon_{i t}
$$

The differential slope coefficient $\delta_{3}$ is found to be negative and statistically significant, suggesting that the impetus of low-growth firms with extra cash to increase dividend is higher than that of high-growth firms. For these firms, the estimated coefficient was 0.408 , while it was 0.282 for high growth firms. A third explanation could be the tendency of the low-growing firms that have extra cash to increase dividends in order to improve their image in the market, which increases their ability to access the equity market to finance any growth in their future investment opportunities.

\section{Discussion}

This study has tested free cash flow hypothesis in the context of an emerging market by using data from non-financial Jordanian firms. Two empirical models have been developed to test the proposition of Jensen (1986) who argues that debt and dividend are assumed to work as a substitute mechanism to reduce the agency cost of free cash flow. Debt and dividend are used as dependent variables with free cash flow as the independent variable. In addition, dummy and interaction dummy forms are used to investigate the effect of firm-specific on the use of debt and dividend to soak up free cash flow. In addition to the pooled data model, the panel data model is used. The data are collected from the firms' annual reports and the Yearly Shareholding Companies Guide available on ASE webpage.

A number of interesting insights have been found. Firstly, of the two models considered to test the proposition of free cash flow, only, the estimated coefficient on the free cash flow variable is found to be statistically significant, suggesting that debt and dividend are not substitute techniques to soak up free cash flow as proposed by free cash flow theory. In both equations, the slope coefficient below one suggests that Jordanian firms use debt as well as dividends to absorb the extra cash generated by these firms, with debt absorbing free cash flow more strictly. Secondly and importantly, the estimated models suggest that firms that have leverage above its target level tend to retire debt not to increase debt, suggesting that the agency cost of debt is higher than that of free cash flow. Moreover, it implies that the bankruptcy costs of debt at level of leverage are too large. Similarly, firms that have already high dividend payments with extra cash leave dividend payment unchanged, supporting the underlying argument of free cash signaling theory not free cash flow theory. For those firms with extra cash 
but below target leverage and have low dividend payment, debt and dividend are used to soak up free cash flow motivated by their willingness to beat their target level.

\section{References}

Adedeji, A. (2002). A cross sectional test of pecking order hypothesis against static trade-off theory on UK Data. Working Paper, University Of Birmingham: UK.

Barclay, M. J., \& Smith, C. W. (1995). The maturity structure of corporate debt. Journal of Finance, 50(2), 609-631. http://dx.doi.org/10.1111/j.1540-6261.1995.tb04797.x

Baskin, J. (1989). An empirical investigation of the pecking order theory. Financial Management, 18, $26-35$. http://dx.doi.org/10.2307/3665695

Bevan, A., \& Danbolt, J. (2004). Testing for inconsistencies in the estimation of UK capital structure determinants. Applied Financial Economics, 14(1), 55-66. http://dx.doi.org/10.1080/0960310042000164220

Cai, F., \& Ghosh, A. (2003). Tests of capital structure theory: a binomial approach. Journal of Business and Economics Studies, 9(2), 20-32.

Charlton, W., Lancaster, C., \& Stevens, J. (2002). Industry and liquidity effects in corporate investment and cash flow relationships. The Journal of Applied Business Research, 18(1), 131-142.

Drake, P. (1977). Securities markets in less-developed countries. Journal of Development Studies, 13(2), 73-91. http://dx.doi.org/10.1080/00220387708421623

Easterbook, F. (1984). Two agency cost explanations of dividends. American Economic Review, 74(4), 650-659.

Fama, E. F., \& French, K. R. (2002). Testing trade-off and pecking order predictions about dividends and debt. The Review of Financial Studies, 15, 1-33. http://dx.doi.org/10.1093/rfs/15.1.1

Fazzari, S., Hubbard, G., \& Petersen, B. (1988). Financing constraints and corporate investment. Brookings Papers on Economic Activity I, 141-195. http://dx.doi.org/10.2307/2534426

Flannery, M. J., \& Rangan, K. P. (2006). Partial adjustment target capital structures. Journal of Financial Economics, 79, 469-506. http://dx.doi.org/10.1016/j.jfineco.2005.03.004

Frank, M., \& Goyal, V. (2003). Testing the pecking order theory of capital structure. Journal of Financial Economics, 67, 217-248. http://dx.doi.org/10.1016/S0304-405X(02)00252-0

Frankfurter, G. M., \& Wood, Jr., B. (2002). Dividend policy theories and their empirical tests. International Review of Financial Analysis, 11, 111-138. http://dx.doi.org/10.1016/S1057-5219(02)00071-6

Gandhi, D., Saunders, A., \& Woodward, R. (1980). Thin capital markets: a case study of the Kuwaiti stock market. Applied Economics, 12(3), 341-349. http://dx.doi.org/10.1080/00036848000000035

Gillan, S., \& Starks, L. T. (2003). Corporate governance, corporate ownership, and the role of institutional investors: a global perspective. Journal of Applied Finance, 13(2), 4-22.

Greene, W. H. (2003). Econometric Analysis. Upper Saddle River, NJ: Prentice Hall.

Grenadier, S. R., \& Wang, N. (2005). Investment timing, agency, and information. Journal of Financial Economics, 75, 493-533. http://dx.doi.org/10.1016/j.jfineco.2004.02.004

Gujarati, D. (2003). Basic econometrics. New York: Irwin/McGraw-Hill.

Harries, M., \& Raviv, A. (1990). Capital structure and the informational role of debt. Journal of Finance, 45(2), 321-349. http://dx.doi.org/10.1111/j.1540-6261.1990.tb03693.x

Harris, M., \& Raviv, A. (1991). The theory of capital structure. Journal of Finance, 32, 297-356. http://dx.doi.org/10.1111/j.1540-6261.1991.tb03753.x

Jensen, M., \& Meckling, W. (1976). The theory of the firm: managerial behavior, agency costs, and ownership structure. Journal of Financial Economics, 3(4), 305-360. http://dx.doi.org/10.1016/0304-405X(76)90026-X

Jensen, M. (1986). Agency cost free cash flow, corporate finance, and takeovers. American Economic Review, $76(2), 323-329$.

Kunt, A., \& Maksimovice, V. (1994). Capital structure in developing countries: evidence from ten countries. Working Paper, The World Bank, Policy Research Paper, No. 1320. 
Lang, L., \& Litzenberger, R. (1989). Dividend announcements, cash flow signaling vs. free cash flow hypothesis. Journal of Financial Economics, 24, 181-191. http://dx.doi.org/10.1016/0304-405X(89)90077-9

Lasfer, M. A. (1995). Agency costs, taxes and debt: the UK evidence. European Financial Management, 1(3), 265-285. http://dx.doi.org/10.1111/j.1468-036X.1995.tb00020.x

Lintner, J. (1956). Distribution of incomes of corporations among dividends, retained earnings, and taxes. American Economic Review, 46, 97-113.

Lo, C. F., \& Hui, C. H. (2009). A note on the dynamics of target leverage ratios. Proceedings of the World Congress on Engineering Vol II.

Maghyereh, A. (2004). The effect of financial liberalization on the efficiency of financial institutions: the case of Jordanian commercial banks. The Journal of Transitional Management Development, 9(2/3), 71-106. http://dx.doi.org/10.1300/J130v09n02_05

Mayer, C. (1990). Financial system, corporate finance, and economic development. In Hubbard, R. G. (Ed.), Asymmetric information, corporate finance, and investment (pp. 297-306). Chicago: University of Chicago and NBER.

Michaely, R., Thaler, R., \& Womack, K. (1995). Price reactions to dividend initiations and omissions: $\begin{array}{llll}\text { overreaction or drift. Journal of Finance, 50, 508. } & \text { 573-608 }\end{array}$ http://dx.doi.org/10.1111/j.1540-6261.1995.tb04796.x

Modigliani, F., \& Miller, M. (1958). The cost of capital, corporate finance and the theory of investment. American Economic Review, 48, 261-297.

Modigliani, F., \& Miller, M. (1963). Corporate income taxes and the cost of capital, a correction. American Economic Review, 53, 433-443.

Myers, S. (1977). Determinants of corporate borrowing. Journal of Financial Economics, 5(2), 147-175. http://dx.doi.org/10.1016/0304-405X(77)90015-0

Myers, S. (1984). The capital structure puzzle. Journal of Finance, 39, 575-592. http://dx.doi.org/10.2307/2327916

Myers, S. (2001). Capital structure. Journal of Economic Perspectives, 15(2), 81-102. http://dx.doi.org/10.1257/jep.15.2.81

Myers, S., \& Majluf, N. (1984). Corporate finance and investment decisions when firms have information that investors do not have. Journal of Financial Economics, 13, 187-221. http://dx.doi.org/10.1016/0304-405X(84)90023-0

Nuri, J., \& Archer, S. (2001). Target adjustment model against pecking order model of capital structure. Working Paper. UK: University of Surrey.

Omet, G. (2004). Dividend policy behavior in the Jordanian capital market. International Journal of Business, 9(3), 1083-4346.

Rajan, R., \& Zingales, L. (1995). What do we know about capital structure? Some evidence from international data. Journal of Finance, 50, 1421-1460. http://dx.doi.org/10.1111/j.1540-6261.1995.tb05184.x

Rozeff, M. S. (1982). Growth, beta and agency costs as determinants of dividend payout ratios. The Journal of Financial Research, 5, 249-259.

Shyam-Sunder, L., \& Myers, S. (1999). Testing static trade-off against pecking order models of capital structure. Journal of Financial Economics, 51(2), 219-244. http://dx.doi.org/10.1016/S0304-405X(98)00051-8

Stulz, R. (1990). Managerial discretion and optimal financing policies. Journal of Financial Economics, 26, 3-27. http://dx.doi.org/10.1016/0304-405X(90)90011-N

Titman, S., \& Wessels, R. (1988). The determinants of capital structure choice. Journal of Finance, 43(1), 1-19. http://dx.doi.org/10.1111/j.1540-6261.1988.tb02585.x

Tong, G., \& Green, C. J. (2005). Pecking order or trade-off hypothesis? Evidence on the capital structure of $\begin{array}{llll}\text { Chinese } & \text { companies. } & \text { Applied } & \text { 2179-2189. }\end{array}$ http://dx.doi.org/10.1080/00036840500319873

Warner, J. (1977). Bankruptcy costs: some evidence. Journal of Finance, 32, 337-347. http://dx.doi.org/10.2307/2326766 
Watts, R. (977). Corporate financial statements: a product of the market and political process. Australian Journal of Management, 2(1), 53-73.

Watts, R., \& Zimmerman, J. (1986). Positive accounting theory. New Jersey: Prentice-Hall.

Williamson, O. E. (1988). Corporate finance and corporate governance. Journal of Finance, 43(3), 567-591. http://dx.doi.org/10.1111/j.1540-6261.1988.tb04592.x

\section{Copyrights}

Copyright for this article is retained by the author(s), with first publication rights granted to the journal.

This is an open-access article distributed under the terms and conditions of the Creative Commons Attribution license (http://creativecommons.org/licenses/by/3.0/). 